DOI: https://doi.org/10.47405/mjssh.v6i1.642

\begin{tabular}{|c|c|}
\hline 4 & Malaysian Journal of Social Sciences and Humanities (MJSSH) \\
\hline $\begin{array}{l}\text { Malaysian Juoural of } \\
\text { Social ccciecces and }\end{array}$ & Volume 6, Issue 1, January 2021 \\
\hline (MJ-sSH) & e-ISSN : 2504-8562 \\
\hline & $\begin{array}{l}\text { Journal home page: } \\
\text { www.msocialsciences.com }\end{array}$ \\
\hline
\end{tabular}

\title{
Kesan Pembelajaran Berasaskan Dokumen dengan Pendekatan Kepelbagaian Sumber Terhadap Pengetahuan Sejarah
}

\author{
M. Kaviza ${ }^{1}$ \\ ${ }_{1}^{1}$ Pusat Pengajian Pendidikan dan Bahasa Moden, Universiti Utara Malaysia (UUM) \\ Correspondence: M. Kaviza (kavizakaviza@yahoo.com)
}

\begin{abstract}
Abstrak
Kajian eksperimen kuasi ini bertujuan untuk mengkaji kesan pembelajaran berasaskan dokumen dengan pendekatan kepelbagaian sumber terhadap pencapaian pengetahuan sejarah. Sampel kajian ini merupakan murid tingkatan satu dari tiga buah sekolah menengah harian yang telah ditentukan berdasarkan teknik persampelan berkelompok. Instrumen kajian ini merupakan ujian pencapaian pengetahuan sejarah yang telah disahkan oleh pakar penilai dan mempunyai nilai ketekalan yang baik. Data kajian ini telah dianalisis secara statistik deskriptif dan inferensi iaitu ujian ANOVA Satu Hala dengan menggunakan perisian IBM SPSS versi 24. Dapatan kajian ini telah melaporkan bahawa pembelajaran berasaskan dokumen dengan pendekatan kepelbagaian sumber adalah lebih berkesan terhadap pencapaian pengetahuan sejarah berbanding dengan pembelajaran berasaskan dokumen tanpa pendekatan kepelbagaian sumber dan pengajaran sedia ada. Implikasi kajian ini telah membuktikan bahawa pembelajaran berasaskan dokumen dengan pendekatan kepelbagaian sumber adalah lebih berpotensi dilaksanakan dalam pendidikan sejarah selaras dengan perkembangan teknologi maklumat dan komunikasi (TMK).
\end{abstract}

Kata kunci: pembelajaran berasaskan dokumen, pendekatan kepelbagaian sumber, pengetahuan sejarah

\section{The Impact of Document Based Learning with Multiple Sources Approach on Historical Knowledge}

\begin{abstract}
The quasi-experimental study aims to examine the impact of document based learning with multiple sources approach on achievement of historical knowledge. The sample of this study is a form one student from three daily secondary schools which were taken using a cluster sampling technique. The research instrument is a test of historical knowledge which has been certified by evaluators in field of history education and has a good reliability of scores, difficulty indices and discrimination indices. The data of this study analyzed using descriptive and inferential (One Ways ANOVA test) statistics using IBM SPSS version 24. The findings of the study show that document based learning with multiple sources approach is more effective in achieving historical knowledge compared to document based learning without multiple sources approach and conventional method. The implication of this study have proven that document based learning with multiple sources approach is more potentially implemented in history education in line with the development of information and communication technology (ICT).
\end{abstract}


Keywords: document based learning, multiple sources approach, historical knowledge

\section{Pengenalan}

Sejarah merupakan suatu disiplin ilmu pengetahuan yang mempunyai prinsip yang tersendiri untuk melihat sesuatu peristiwa masa lampau melalui dimensi kaca mata masa kini berdasarkan proses penyelidikan dengan menggunakan rekod-rekod terdahulu (Abdul Rahman, 2006; Khoo, 1992). Sehubungan dengan itu, ilmu sejarah kini semakin diberi perhatian dalam sistem pendidikan Malaysia melalui pemartabatan mata pelajaran sejarah sebagai mata pelajaran wajib lulus dalam peperiksaan awam iaitu Sijil Pelajaran Malaysia (SPM) dan pelaksanaan semula mata pelajaran Sejarah sebagai mata pelajaran teras di sekolah rendah secara berterusan hingga ke sekolah menengah melalui Kurikulum Standard Sekolah Rendah (KSSR) dan Kurikulum Standard Sekolah Menengah (KSSM) (Abdul Razaq \& Ahmad Rafaai, 2011; Mohd Samsudin \& Shahizan, 2012; Norizan Seman, 2003; Pusat Perkembangan Kurikulum [PPK], 2013, 2015). Namun, kedua-dua pemartabatan mata pelajaran sejarah tersebut tidak dapat direalisasikan sekiranya murid-murid hanya terlibat dengan kaedah pengajaran konvensional yang berorientasikan kepada penghafalan fakta dan maklumat sejarah semata-mata yang bermatlamat untuk lulus dalam peperiksaan sahaja (Abdul Razaq \& Andi, 2007; Mohd Rodzi, 2009). Maka, kaedah pembelajaran Sejarah mestilah memfokuskan kepada proses pemahaman terhadap ilmu sejarah yang melibatkan aspek penguasaan kandungan sejarah (Abdul Razaq, 2010; Sharifah \& Arba'iyah, 2016; Thangamalar \& Nagendralingam, 2018). Adalah diakui bahawa pengetahuan sejarah merupakan antara komponen utama dalam kerangka disiplin ilmu sejarah yang ditekankan dalam kurikulum sejarah (PPK, 2003; 2015). Hal ini kerana komponen pengetahuan sejarah adalah melibatkan proses pemahaman dan penghayatan tentang fakta, konsep, idea dan maklumat sejarah yang perlu dipelajari secara kronologi mengikut topik atau tema sejarah dalam mata pelajaran sejarah secara berterusan (Brooks, 2013; Counsell, 2000; Roberts, 2011; Tan, 2004; Tyman, McCleery \& Tindal, 2006). Justeru, penerapan komponen pengetahuan sejarah dalam kurikulum sejarah adalah sangat penting dan tidak boleh diabaikan lagi kerana melibatkan proses menaakul dengan menguasai kandungan sejarah seperti tokoh, masa, lokasi dan konsep sejarah yang khusus bagi membentuk pola pemikiran dan pemahaman sejarah yang unik dalam kalangan murid (Booth, 1983; Deborah, 2012; Levisohn, 2015; Mink, 1987; Sheehan, 2013; Zaccaria, 1978).

Hakikatnya, tidak dapat disangkal bahawa asas kepada pembelajaran sejarah adalah sumber dokumen sejarah yang dijadikan bahan bukti bertulis dalam membuat suatu interpretasi sejarah yang telah berlaku seperti surat khabar, surat, diari, rekod keluarga, rekod banci, dokumen rasmi, pelan bangunan, data statistik, manuskrip sejarah, ensiklopedia, buku sejarah dan sebagainya (Donnelly \& Claire, 2011; Poulton, 1972; Thornton, 2005) yang boleh diperoleh dalam format analog (bercetak) dan digital (elektronik) daripada portal-portal dan laman-laman web sejarah yang dibangunkan secara percuma (Alves, 2014; Brown, 2007; Chassanoff, 2013; Friedman, 2006; Fry \& Ensmiger, 2008; Lee, 2002; Putnam, 2016). Justeru, pembelajaran berasaskan dokumen semakin berkembang pesat sejak abad ke-19 lagi pada semua peringkat persekolahan yang dirujuk sebagai strategi pembelajaran sejarah yang melibatkan proses inkuiri dan analisis kandungan sumber yang berbentuk teks dan telah dibuktikan dapat memberikan manfaat dari segi menggalakkan penglibatan aktif dalam aktiviti pembelajaran bersifat autentik dan proses penghujahan dan penaakulan secara logik dan bernas (Barton, 2018; Breakstone, McGrew, Smith, Ortega \& Wineburg, 2018; Colby, 2008; Cowgill, 2015; Hover, Hicks \& Dack, 2016; Johansson, 2017; Learned, 2018; Samuelsson \& Wendell, 2016; Wosyhner, 2010). Sungguhpun proses pembelajaran berasaskan dokumen didapati memberikan banyak manfaat, namun timbul persoalan tentang penggunaan pendekatan kepelbagaian sumber dalam pembelajaran berasaskan dokumen selaras dengan perkembangan Teknologi Maklumat dan Komunikasi (TMK) dalam pendidikan sejarah yang menggalakkan pengintegrasian kepelbagaian jenis sumber atau bahan yang berbentuk visual, video, audio dan sebagainya dalam proses pengajaran dan pembelajaran sejarah (Britt \& Rouet, 2011; Donnelly, 2018; Merkt, Werner \& Wagner, 2017; Moser, 2013; Nokes, 2014; Reisman, 2012). Persoalan tentang keperluan penggunaan pendekatan kepelbagaian sumber dalam pembelajaran berasaskan dokumen turut didapati oleh pengkaji dalam 
kajian ini berdasarkan pelaksanaan pembelajaran berasaskan dokumen tersebut dalam kalangan murid tingkatan empat yang telah mencadangkan kepada kajian lanjutan yang perlu diterokai (Kaviza, 2019). Hal ini demikian kerana pemerolehan maklumat sejarah daripada sumber-sumber teks sahaja berkemungkinan boleh mengehadkan pencapaian, pemahaman dan penguasaan pengetahuan sejarah yang ditetapkan dalam kurikulum sejarah (Hastings, Hughes, Magliano \& Goldman, 2012; Hynd, 1999; Rouet, Britt, Mason \& Perfetti, 1996; VanSledright \& Kelly, 1998). Maka, keberkesanan penggunaan pendekatan kepelbagaian sumber dalam pembelajaran berasaskan dokumen sama ada dapat meningkatkan pengetahuan sejarah atau sebaliknya dalam kalangan murid perlu dikenal pasti sejajar untuk mewujudkan proses persekitaran pembelajaran sejarah yang lebih bermakna seperti yang disarankan dalam kurikulum sejarah. Hal ini demikian kerana murid-murid didapati masih lemah dalam memahami kandungan ilmu sejarah yang melibatkan fakta, konsep dan maklumat sejarah yang bersifat kompleks, abstrak dan sukar difahami dengan lebih mudah (Malar, 2015; Nur Syazwani, Kamarulzaman \& Nur Azuki, 2016). Tambahan pula, Anuar, Siti Haishah dan Nur Atiqah T. Abdullah (2009) dan Lezah dan Rosy (2018) dalam kajiannya turut telah melaporkan bahawa kaedah pengajaran sejarah, khususnya kemahiran mengajar guru sejarah serta pelaksanaan kaedah pembelajaran sejarah yang inovatif didapati mempunyai hubungan dan kaitan dengan peningkatan pencapaian sejarah dalam kalangan murid yang telah memaparkan terdapat satu keperluan kepada pengkaji dalam kajian ini untuk mengkaji kesan pembelajaran berasaskan dokumen dengan pendekatan kepelbagaian sumber terhadap pencapaian pengetahuan sejarah.

\section{Tujuan Kajian}

Kajian ini bertujuan untuk:

i. Mengkaji kesan pembelajaran berasaskan dokumen dengan pendekatan kepelbagaian sumber terhadap pencapaian pengetahuan sejarah.

\section{Objektif Kajian}

Objektif kajian ini ialah:

i. Mengenal pasti sama ada terdapat perbezaan min skor pencapaian pengetahuan sejarah bagi murid yang mengikuti pembelajaran berasaskan dokumen dengan pendekatan kepelbagaian sumber berbanding dengan murid yang mengikuti pembelajaran berasaskan dokumen tanpa pendekatan kepelbagaian sumber dan murid yang mengikuti pengajaran sedia ada dalam ujian pra.

ii. Mengenal pasti sama ada terdapat perbezaan min skor pencapaian pengetahuan sejarah bagi murid yang mengikuti pembelajaran berasaskan dokumen dengan pendekatan kepelbagaian sumber berbanding dengan murid yang mengikuti pembelajaran berasaskan dokumen tanpa pendekatan kepelbagaian sumber dan murid yang mengikuti pengajaran sedia ada dalam ujian pasca.

\section{Persoalan Kajian}

Persoalan kajian ini ialah:

i. Adakah terdapat perbezaan min skor pencapaian pengetahuan sejarah bagi murid yang mengikuti pembelajaran berasaskan dokumen dengan pendekatan kepelbagaian sumber berbanding dengan murid yang mengikuti pembelajaran berasaskan dokumen tanpa pendekatan kepelbagaian sumber dan murid yang mengikuti pengajaran sedia ada dalam ujian pra?

ii. Adakah terdapat perbezaan min skor pencapaian pengetahuan sejarah bagi murid yang mengikuti pembelajaran berasaskan dokumen dengan pendekatan kepelbagaian sumber berbanding dengan murid yang mengikuti pembelajaran berasaskan dokumen tanpa 
pendekatan kepelbagaian sumber dan murid yang mengikuti pengajaran sedia ada dalam ujian pasca?

\section{Hipotesis Kajian}

Dua hipotesis nul (Ho) telah dibentuk bagi diuji kesignifikannya pada aras $p=0.05$ adalah seperti berikut:

$\mathrm{Ho}_{1}$ : Tidak terdapat perbezaan min skor pencapaian pengetahuan sejarah yang signifikan bagi murid yang mengikuti pembelajaran berasaskan dokumen dengan pendekatan kepelbagaian sumber berbanding dengan murid yang mengikuti pembelajaran berasaskan dokumen tanpa pendekatan kepelbagaian sumber dan murid yang mengikuti pengajaran sedia ada dalam ujian pra.

$\mathrm{Ho}_{2}$ : Tidak terdapat perbezaan min skor pencapaian pengetahuan sejarah yang signifikan bagi murid yang mengikuti pembelajaran berasaskan dokumen dengan pendekatan kepelbagaian sumber berbanding dengan murid yang mengikuti pembelajaran berasaskan dokumen tanpa pendekatan kepelbagaian sumber dan murid yang mengikuti pengajaran sedia ada dalam ujian pasca.

\section{Metod Kajian}

Kajian kuantitatif melalui eksperimen kuasi (Cook \& Campbell, 1979) digunakan untuk menentukan pengukuran keberkesanan pengetahuan sejarah yang melibatkan kumpulan murid yang mengikuti pembelajaran berasaskan dokumen dengan pendekatan kepelbagaian sumber (kumpulan eksperimen pertama), kumpulan murid yang mengikuti pembelajaran berasaskan dokumen tanpa pendekatan kepelbagaian sumber (kumpulan eksperimen kedua) dan kumpulan murid yang mengikuti pembelajaran sedia ada (kumpulan kawalan). Kajian ini melibatkan murid-murid Tingkatan Satu dari tiga buah sekolah menengah harian yang telah ditentukan berdasarkan teknik persampelan berkelompok iaitu 34 orang murid (kumpulan eksperimen pertama) dan 33 orang murid (kumpulan eksperimen kedua) dan 35 orang murid (kumpulan kawalan). Instrumen kajian ini merupakan ujian pencapaian pengetahuan sejarah berbentuk item objektif yang dibina oleh pengkaji dan telah disahkan oleh pakar penilai dalam bidang sejarah. Nilai ketekalan instrumen [Kuder Richardson $20\left(\mathrm{KR}_{20}\right)$ ] iaitu 0.87 serta nilai kesukaran (antara 0.30 hingga 0.69) dan nilai diskriminasi (antara 0.41 hingga 0.64) adalah baik dan diterima bagi tujuan kajian ini (Ebel \& Frisbie, 1991; Kaplan \& Saccuzzo, 2009; Nunnally, 1978). Data kajian ini dianalisis secara deskriptif dan inferensi iaitu ANOVA Satu Hala melalui perisian IBM SPSS versi 24. Murid-murid mengikuti pembelajaran sejarah bagi Tamadun Awal Dunia dalam kajian ini.

\section{Dapatan Kajian}

Persoalan kajian 1: Adakah terdapat perbezaan min skor pencapaian pengetahuan sejarah bagi murid yang mengikuti pembelajaran berasaskan dokumen dengan pendekatan kepelbagaian sumber berbanding dengan murid yang mengikuti pembelajaran berasaskan dokumen tanpa pendekatan kepelbagaian sumber dan murid yang mengikuti pengajaran sedia ada dalam ujian pra?

$\mathrm{Ho}_{1}$ : Tidak terdapat perbezaan pencapaian min skor pengetahuan sejarah yang signifikan bagi murid yang mengikuti pembelajaran berasaskan dokumen dengan pendekatan kepelbagaian sumber berbanding dengan murid yang mengikuti pembelajaran berasaskan dokumen tanpa pendekatan kepelbagaian sumber dan murid yang mengikuti pengajaran sedia ada dalam ujian pra.

Statistik deskriptif pada Jadual 1 telah menunjukkan bahawa min skor ujian pra pencapaian pengetahuan sejarah dalam kajian ini ialah bagi kumpulan eksperimen pertama $(M=8.88, S D=2.60)$, bagi kumpulan eksperimen kedua $(M=8.91, S D=2.64)$ dan bagi kumpulan kawalan $(M=8.80$, $S D=2.61$ ). Walaubagaimanapun, min skor ujian pra pencapaian pengetahuan sejarah adalah lebih 
DOI: https://doi.org/10.47405/mjssh.v6i1.642

tinggi bagi kumpulan eksperimen kedua berbanding dengan kumpulan eksperimen pertama dan kumpulan kawalan. Berdasarkan nilai ujian Levene's yang tidak signifikan $[F(2,99)=0.01, p=0.99]$ pada Jadual 2 menunjukkan bahawa varians antara ketiga-tiga kumpulan tersebut adalah setara (Green \& Salkind, 2017; Griffith, 2010; Pallant, 2016), maka dapatan ujian ANOVA Satu Hala yang dijalankan pada Jadual 3 telah menunjukkan bahawa tidak terdapat perbezaan min skor ujian pra pencapaian pengetahuan sejarah yang signifikan antara kumpulan eksperimen pertama, kumpulan eksperimen kedua dan kumpulan kawalan $[F(2,99)=0.02, p=0.98]$. Oleh sebab tidak terdapat perbezaan min skor ujian pra yang signifikan terhadap pencapaian pengetahuan sejarah dalam kajian ini, maka ujian perbandingan pelbagai Post Hoc tidak dapat dijalankan. Maka, hipotesis nul $\left(\mathrm{H}_{\mathrm{ol}}\right)$ telah diterima iaitu tidak terdapat perbezaan pencapaian min skor pengetahuan sejarah yang signifikan bagi murid yang mengikuti pembelajaran berasaskan dokumen dengan pendekatan kepelbagaian sumber berbanding dengan murid yang mengikuti pembelajaran berasaskan dokumen tanpa pendekatan kepelbagaian sumber dan murid yang mengikuti pengajaran sedia ada dalam ujian pra. Justeru, dapat disimpulkan bahawa min skor ujian pra pencapaian pengetahuan sejarah adalah setara bagi murid dalam kumpulan eksperimen pertama, kumpulan eksperimen kedua dan kumpulan kawalan dalam kajian ini.

Jadual 1: Statistik Deskriptif Bagi Min Skor Ujian Pra dan Ujian Pasca Pengetahuan Sejarah

\begin{tabular}{|c|c|c|c|c|c|c|}
\hline & \multicolumn{2}{|c|}{ Eksperimen pertama } & \multicolumn{2}{|c|}{ Eksperimen kedua } & \multicolumn{2}{|c|}{ Kawalan } \\
\hline & Pra & Pasca & Pra & Pasca & Pra & Pasca \\
\hline $\mathbf{N}$ & 34 & & 33 & & 35 & \\
\hline Min & 8.88 & 23.47 & 8.91 & 19.88 & 8.80 & 11.51 \\
\hline$S D$ & 2.60 & 3.77 & 2.64 & 3.15 & 2.61 & 3.45 \\
\hline
\end{tabular}

Jadual 2: Ujian Levene’s Kesetaraan Varians Bagi Min Skor Ujian Pra Pengetahuan Sejarah

\begin{tabular}{llll}
\hline F & df1 & df 2 & p \\
\hline 0.01 & 2 & 99 & 0.99 \\
\hline
\end{tabular}

Jadual 3: Keputusan Ujian Kesan Variabel Antara Subjek Untuk Min Skor Ujian Pra Pengetahuan Sejarah

\begin{tabular}{llllll}
\hline & $\begin{array}{l}\text { Jumlah } \\
\text { kuasa Dua }\end{array}$ & $\boldsymbol{d f}$ & $\begin{array}{l}\text { Min Kuasa } \\
\text { Dua }\end{array}$ & $\boldsymbol{F}$ & $\boldsymbol{p}$ \\
\hline Antara Kumpulan & 0.22 & 2 & 0.11 & 0.02 & 0.98 \\
Dalam Kumpulan & 677.86 & 99 & 6.85 & & \\
Jumlah & 678.08 & 101 & & & \\
\hline
\end{tabular}

Pada aras kesignifikan $(p=0.05)$

Persoalan Kajian 2: Adakah terdapat perbezaan min skor pencapaian pengetahuan sejarah bagi murid yang mengikuti pembelajaran berasaskan dokumen dengan pendekatan kepelbagaian sumber berbanding dengan murid yang mengikuti pembelajaran berasaskan dokumen tanpa pendekatan kepelbagaian sumber dan murid yang mengikuti pengajaran sedia ada dalam ujian pasca?

$\mathrm{Ho}_{2}$ : Tidak terdapat perbezaan min skor pencapaian pengetahuan sejarah yang signifikan bagi murid yang mengikuti pembelajaran berasaskan dokumen dengan pendekatan kepelbagaian sumber berbanding dengan murid yang mengikuti pembelajaran berasaskan dokumen tanpa pendekatan kepelbagaian sumber dan murid yang mengikuti pengajaran sedia ada dalam ujian pasca.

Statistik deskriptif pada Jadual 1 telah menunjukkan bahawa min skor ujian pasca pencapaian pengetahuan sejarah adalah lebih tinggi bagi kumpulan eksperimen pertama $(M=23.47, S D=3.77)$ berbanding dengan kumpulan eksperimen kedua $(M=19.88, S D=3.15)$ dan kumpulan kawalan 
DOI: https://doi.org/10.47405/mjssh.v6i1.642

$(M=11.51, S D=3.47)$ dalam kajian ini. Berdasarkan nilai ujian Levene's yang tidak signifikan $[F(2$, 99) $=0.90, p=0.41]$ pada Jadual 4 menunjukkan bahawa varians antara ketiga-tiga kumpulan tersebut adalah setara (Green \& Salkind, 2017; Griffith, 2010; Pallant, 2016), maka dapatan ujian ANOVA Satu Hala yang dijalankan pada Jadual 5 telah menunjukkan bahawa terdapat perbezaan min skor ujian pasca pencapaian pengetahuan sejarah yang signifikan antara kumpulan eksperimen pertama, kumpulan eksperimen kedua dan kumpulan kawalan $[F(2,99)=107.80, p=0.00]$.

Jadual 4: Ujian Levene's Kesetaraan Varians Bagi Min Skor Ujian Pasca Pencapaian Pengetahuan Sejarah

\begin{tabular}{llll}
\hline F & df1 & df 2 & p \\
\hline 0.90 & 2 & 99 & 0.41 \\
\hline
\end{tabular}

Jadual 5: Keputusan Ujian Kesan Variabel Antara Subjek Untuk Min Skor Ujian Pasca Pencapaian Pengetahuan Sejarah

\begin{tabular}{llllll}
\hline & $\begin{array}{l}\text { Jumlah } \\
\text { kuasa Dua }\end{array}$ & $\boldsymbol{d f}$ & $\begin{array}{l}\text { Min Kuasa } \\
\text { Dua }\end{array}$ & $\boldsymbol{F}$ & $\boldsymbol{p}$ \\
\hline Antara Kumpulan & 2601.95 & 2 & 1300.97 & 107.80 & 0.00 \\
Dalam Kumpulan & 1194.73 & 99 & 12.07 & & \\
Jumlah & 3796.68 & 101 & & & \\
\hline
\end{tabular}

Pada aras kesignifikan $(p=0.05)$

Oleh sebab terdapat perbezaan min skor ujian pasca yang signifikan terhadap pencapaian pengetahuan sejarah dalam kajian ini, maka ujian perbandingan pelbagai Post Hoc telah dijalankan. Dapatan ujian perbandingan pelbagai Post Hoc Sidak pada Jadual 6 telah menunjukkan bahawa:

a) Kumpulan eksperimen pertama mendapat min skor pencapaian pengetahuan sejarah yang lebih tinggi secara signifikan berbanding dengan kumpulan eksperimen kedua (perbezaan min kumpulan eksperimen pertama - kumpulan eksperimen kedua $=3.59, p=0.00$ ) dan kumpulan kawalan (perbezaan min kumpulan eksperimen pertama - kumpulan kawalan=11.96, $p=0.00$ ).

b) Kumpulan eksperimen kedua mendapat min skor pencapaian pengetahuan sejarah yang lebih rendah berbanding dengan kumpulan eksperimen pertama (perbezaan min kumpulan eksperimen kedua - kumpulan eksperimen pertama $=-3.59, p=0.00$ ) dan min skor pencapaian pengetahuan sejarah yang lebih tinggi secara signifikan daripada kumpulan kawalan (perbezaan min kumpulan eksperimen kedua - kumpulan kawalan=8.36, $p=0.00$ ).

c) Kumpulan kawalan mendapat min skor pencapaian pengetahuan sejarah yang lebih rendah berbanding dengan kumpulan eksperimen pertama (perbezaan min kumpulan kawalan kumpulan eksperimen pertama $=-11.96, p=0.00$ ) dan kumpulan eksperimen kedua (perbezaan min kumpulan kawalan - kumpulan eksperimen kedua $=-8.36, p=0.00$ ).

Oleh kerana dapatan ujian perbandingan pelbagai Post Hoc Sidak telah menunjukkan bahawa min skor ujian pasca pencapaian pengetahuan sejarah adalah lebih tinggi bagi murid dalam kumpulan eksperimen pertama berbanding dengan kumpulan eksperimen kedua dan kumpulan kawalan, maka, hipotesis nul $\left(\mathrm{H}_{\mathrm{o} 2}\right)$ telah berjaya ditolak iaitu terdapat perbezaan pencapaian min skor pengetahuan sejarah yang signifikan bagi murid yang mengikuti pembelajaran berasaskan dokumen dengan pendekatan kepelbagaian sumber berbanding dengan murid yang mengikuti pembelajaran berasaskan dokumen tanpa pendekatan kepelbagaian sumber dan murid yang mengikuti pengajaran sedia ada dalam ujian pasca. Justeru, dapat disimpulkan bahawa pembelajaran berasaskan dokumen dengan pendekatan kepelbagaian sumber adalah lebih berkesan terhadap pencapaian pengetahuan sejarah dalam kajian ini. 
DOI: https://doi.org/10.47405/mjssh.v6i1.642

Jadual 6: Keputusan Ujian Perbandingan Pelbagai Post Hoc Sidak Untuk Min Skor Pencapaian Pengetahuan Sejarah Berdasarkan Kaedah Pengajaran

\begin{tabular}{|c|c|c|c|c|c|c|}
\hline \multirow[t]{2}{*}{$\begin{array}{l}\text { I } \\
\text { Kumpulan }\end{array}$} & \multirow[t]{2}{*}{$\begin{array}{l}\text { J } \\
\text { Kumpulan }\end{array}$} & \multirow[t]{2}{*}{$\begin{array}{l}\text { Perbezaan } \\
\text { Min }\end{array}$} & \multirow[t]{2}{*}{$\begin{array}{l}\text { Ralat } \\
\text { Piawai }\end{array}$} & \multirow[t]{2}{*}{$p$} & \multicolumn{2}{|c|}{$\begin{array}{l}95 \% \text { selang keyakinan } \\
\text { bagi perbezaan }\end{array}$} \\
\hline & & & & & Bawah & Atas \\
\hline \multirow{2}{*}{ Eksp 1} & Eksp 2 & $3.59 *$ & 0.85 & 0.00 & 1.53 & 5.65 \\
\hline & Kawalan & $11.96^{*}$ & 0.84 & 0.00 & 9.92 & 13.99 \\
\hline \multirow[t]{2}{*}{ Eksp 2} & Eksp 1 & $-3.59 *$ & 0.85 & 0.00 & -5.65 & -1.53 \\
\hline & Kawalan & $8.36^{*}$ & 0.84 & 0.00 & 6.32 & 10.41 \\
\hline \multirow[t]{2}{*}{ Kawalan } & Eksp 1 & $-11.96^{*}$ & 0.84 & 0.00 & -13.99 & -9.92 \\
\hline & Eksp 2 & $-8.36^{*}$ & 0.84 & 0.00 & -10.41 & -6.32 \\
\hline
\end{tabular}

Nota: $($ Eksp 1= Eksperimen pertama, Eksp 2= Eksperimen kedua $)$

Berdasarkan estimated marginal means

*Pada aras kesignifikan $(p=0.05)$

\section{Perbincangan Kajian}

Hasil dapatan kajian ini mendapati bahawa murid yang menjalani pembelajaran berasaskan dokumen dengan pendekatan kepelbagaian sumber telah menunjukkan pencapaian pengetahuan sejarah yang lebih baik berbanding dengan murid yang mengikuti pembelajaran berasaskan dokumen tanpa pendekatan kepelbagaian sumber dan murid yang mengikuti pengajaran sedia ada. Selain itu, murid yang menjalani pembelajaran berasaskan dokumen tanpa pendekatan kepelbagaian sumber pula melaporkan pencapaian pengetahuan sejarah yang lebih baik berbanding dengan murid yang menjalani pengajaran sedia ada. Justeru itu, hasil dapatan kajian ini telah membuktikan bahawa pelaksanaan pembelajaran berasaskan dokumen, terutama dengan penggunaan pendekatan kepelbagaian sumber menjadi faktor yang menyumbang kepada pencapaian pengetahuan sejarah yang lebih tinggi dalam kalangan murid berbanding dengan murid yang mengikuti pembelajaran berasaskan dokumen tanpa pendekatan kepelbagaian sumber dan pengajaran sedia ada.

Dapatan kajian ini adalah selaras dengan Teori Pembelajaran Konstruktivisme yang telah menjelaskan bahawa pembelajaran berasaskan bahan dapat menggalakkan proses pemerolehan dan pemahaman serta penguasaan pengetahuan sejarah dengan menjana kemahiran menaakul sejarah yang baik bagi membentuk konteks persekitaran pembelajaran yang bermakna (Duffy \& Cunningham, 1996; Gagnon \& Collay, 2001; Haycock, 1991; Hill \& Hannafin, 2001). Pencapaian pengetahuan sejarah yang lebih tinggi yang telah dipamerkan oleh murid yang menjalani pembelajaran berasaskan dokumen dengan pendekatan kepelbagaian sumber berbanding murid yang menjalani pembelajaran berasaskan dokumen tanpa pendekatan kepelbagaian sumber dan dapatan ini adalah konsisten dengan Teori Keluwesan Kognitif (Spiro, Coulson, Feltovisch, \& Anderson, 1988; Spiro \& Jehng, 1990) yang menjelaskan bahawa murid dapat membuat pengkonsepsian, pemerolehan, pengaplikasian dan pengekalan pengetahuan pada konteks yang lain apabila mereka didedahkan dalam pembelajaran berasaskan dokumen dengan pendekatan kepelbagaian sumber yang melibatkan penggunaan pelbagai jenis sumber sejarah yang berlainan format. Justeru, murid yang menjalani pembelajaran berasaskan dokumen berkemungkinan menghadapi kekurangan pemerolehan pengetahuan sejarah yang berpandukan hanya kepada satu sumber teks sahaja yang telah mengehadkan pembentukan proses pemahaman, penguasaan dan pencapaian pengetahuan sejarah dalam kalangan murid (Allen, 2011; Reisman, 2017; Richter \& Maier, 2017). Hasil dapatan kajian ini adalah selaras dengan kajian Callahan (2013), Chick (2006), Fertig (2008), Hendrickson (2016), Oppong (2012), Stephens, Lehr, Thorp, Ewing dan Hicks (2005), Sell dan Griffin (2017) dan Suh (2013) yang telah melaporkan bahawa penggunaan sumber sejarah seperti lukisan, muzik, sajak, puisi, novel, fotograf bahan arkeologi, poster, koleksi khas artifak, bibliografi tokoh, sumber digital dan sumber lisan telah membolehkan murid-murid dapat menerangkan semula isi kandungan sejarah dengan lebih baik dari 
segi lokasi, masa dan tempat, di samping mereka dapat mempersoalkan kebenaran sesuatu peristiwa sejarah tersebut.

Sungguhpun begitu, Wagner (2018) dalam kajiannya pula telah membuktikan bahawa penggunaan sumber filem sejarah dalam proses pengajaran dan pembelajaran Sejarah di sekolah menengah tinggi di Norwegian dapat meningkatkan pencapaian pengetahuan sejarah yang lebih baik walaupun penggunaan sumber sejarah tersebut dibatasi dengan masalah masa pengajaran yang tidak mencukupi dan pemilihan filem sejarah yang bersesuaian dengan topik pelajaran. Selain itu, dapatan kajian Tomsic dan Deery (2019) yang telah melaporkan bahawa penggunaan sumber sejarah berbentuk gambar melalui cerita kanak-kanak dalam bahasa Inggeris adalah berperanan sebagai bahan pengajaran sejarah yang dapat menyediakan ruang penerokaan idea dan maklumat sejarah serta penguasaan pengetahuan sejarah berkaitan dengan krisis contemporary refugee telah menyokong dapatan kajian ini. Natijahnya, kedua-dua dapatan kajian Tomsic dan Deery (2019) dan Wagner (2018) yang empirikal tersebut adalah konsisten dengan pendapat Donnelly (2014) yang menjelaskan kepentingan penggunaan filem dalam proses pengajaran dan pembelajaran Sejarah dan pendapat Fehn dan Schul (2011) yang membincangkan tatacara pembinaan, pelaksanaan dan penilaian penggunaan filem dokumentari sejarah yang bertemakan hari kebangsaan dalam mata pelajaran Sejarah. Justeru, kesemua dapatan kajian tersebut (Callahan, 2013; Chick, 2006; Fehn \& Schul, 2011; Oppong, 2012; Suh, 2013; Tomsic \& Deery, 2019; Wagner, 2017) adalah selaras dengan Teori Perkembangan Kognitif Piaget (Piaget, 1952, 1970) yang menjelaskan bahawa pencapaian pengetahuan sejarah secara empati dapat dibentuk apabila murid-murid yang berumur antara 12 tahun ke atas yang berada pada peringkat operasi formal adalah berupaya untuk membuat refleksi terhadap cara pengetahuan tersebut diperolehi dengan mempertimbangkan peranan dan sifat semula jadi maklumat dan pengetahuan sejarah tersebut daripada pelbagai konteks pengkajian sejarah secara terarah kendiri. Oleh itu, dapat dirumuskan bahawa pembelajaran berasaskan dokumen dengan pendekatan kepelbagaian sumber adalah lebih berkesan terhadap pencapaian pengetahuan sejarah dalam kalangan murid.

\section{Kesimpulan}

Kesimpulannya, pembelajaran berasaskan dokumen dengan pendekatan kepelbagaian sumber dalam kajian ini didapati dapat meningkatkan pengetahuan sejarah yang lebih baik dalam kalangan murid berbanding dengan murid yang mengikuti pembelajaran berasaskan dokumen tanpa pendekatan kepelbagaian sumber dan murid yang mengikuti pengajaran sedia ada. Hal ini demikian kerana muridmurid dapat menguasai dan memahami sesuatu peristiwa sejarah dengan lebih mendalam dan memperoleh suatu gambaran yang menyeluruh terhadap peristiwa sejarah tersebut. Oleh itu, proses pembelajaran yang lebih bermakna dapat dibentuk apabila murid-murid berjaya meningkatkan pengetahuan sejarah seperti yang disarankan dalam kurikulum sejarah apabila mereka berperanan sebagai seorang ahli sejarah dalam melakukan proses pengkajian sejarah secara lebih mendalam di dalam kelas.

\section{Rujukan}

Abdul Rahman Haji Abdullah. (2006). Pengantar ilmu sejarah. Kuala Lumpur: Dewan Bahasa dan Pustaka.

Abdul Razaq Ahmad \& Andi Suwarirta. (2007). Sejarah dan pendidikan sejarah: Perspektif Malaysia dan Indonesia. Bandung: Historia Utama Press.

Abdul Razaq Ahmad (2010). The acquisition of conceptual understanding of historical thinking in the context of multi-ethnic students in Malaysia. Historia: Jurnal Pendidik dan Peneliti Sejarah, 10(2), 108-119.

Ahmad Razaq Ahmad \& Ahmad Rafaai Ayudin. (2011). History curriculum development model towards nation building of Malaysia. Historia: Jurnal Pendidik dan Peneliti Sejarah, 12(1), 4052. 
Allen, R.B. (2011, Ogos). Developing a knowledge-based to improve interaction with collections of historical newspapers. Kertas kerja yang dibentangkan di International Federation of Library Association (IFLA), San Juan, Puerto Rico.

Alves, D. (2014). Introduction: digital methods and tools for historical research. International Journal of Humanities and Arts Computing, 8(1), 1-12.

Anuar Ahmad, Siti Haishah Abd. Rahman, \& Nur Atiqah T.Abdullah. (2009). Tahap Keupayaan Pengajaran Guru Sejarah dan hubunganya dengan pencapaian murid di sekolah berprestasi rendah. Jurnal Pendidikan Malaysia, 34(1), 53-66.

Barton, K.C. (2018). Historical sources in the classroom: Purpose and use. HSSE Online, 7(2), 1-11.

Booth, M.B. (1983). Skills, concepts, and attitudes: the development of adolescent children's historical thinking. History and Theory, 22(4), 101-117.

Breakstone, J., McGrew, S., Smith, M., Ortega, T., \& Wineburg, S. (2018). Why we need a new approach of teaching digital literacy. Kappan, 99(6), 27-32.

Britt, M.A., \& Rouet, J.F. (2011). Research challenges in the use of multiple documents. International Design Journal, 19(1), 62-68. doi:10.1075/idj.18108br

Brooks, S. (2013). Teaching for historical understanding in the advanced placement program: A case study. The History Teacher, 47(1), 61-76.

Brown, C.A. (2007). Using digital primary sources: A success story in collaboration. Teacher Librarian, 35(2), 29-33

Callahan, C. (2013). Analyzing historical photographs to promote civic competence. Social Studies Research \& Practice, 8(1), 77-88.

Chassanoff, A. (2013). Historians and the use of primary source materials in the digital age. The American Archivist, 76(2), 458-479.

Chick, K.A. (2006). Fostering student collaboration through the use of historical picture books. The Social Studies, 152-157.

Colby, S.R. (2008). Energizing the history classroom: Historical narrative inquiry and historical empathy. Social Studies Research and Practice, 3(3), 60-79.

Cook, T, D., \& Campbell, D.T. (1979). Quasi-experimentation: Design and analysis issues for field settings. Boston: Houghton Mifflin.

Counsell, C. (2000). Historical knowledge and historical skills: A distracting dichotomy issues in History Teaching. United Kingdom: Routledge.

Cowgill II, D.A. (2015). Primary sources in the social studies classroom: Historical inquiry with book backdrops. Social Studies Research and Practice, 10(1), 65-83.

Deborah, J.H. (2012). Engaging students in historical thinking: Implementing the Australian history curriculum. Primary and Middle Years Educator, 10(1), 3-11. doi:10.108/00131857.2015.1101363

Donnelly, D. (2014). Using feature films in teaching historical understanding: research and practice. AGORA, 4-12.

Donnelly, D.J. (2018). Contemporary multimodal historical representations and the teaching of disciplinary understandings in history. Journal of International Social Studies, 8(1), 113-132.

Donnelly, M., \& Claire, N. (2011). Doing History. United State America: Routledge

Duffy, T.M., \& Cunningham, D.J. (1996). Constructivism: Implications for the design and delivery of instruction. In D.H. Jonassen (Eds.), Handbook of research for educational communications and technology (pp. 170-198). New York: Schuster Macmillan.

Ebel, R.L., \& Frishie, D.A. (1991). Essential of educational measurement (5 $5^{\text {th }}$ ed.). New Delhi: Prentice-Hall of India.

Fehn, B., \& Schul, J, F. (2014). Selective appropriation and historical documentary making in special education classroom. Social Studies Research and Practice, 9(2), 1- 14. Fertig, G. (2008). Using biography to help young learners understand the causes of historical change and continuity. The Social Studies, 99(4), 147-154. doi:10.32000/TSSS.99.4

Friedman, A.M. (2006). World history teacher's use of digital primary sources: The effect of training. Theory \& Research in Social Education, 34(1), 124-141.

Fry, M.L., \& Ensminger, D.C. (2008). Integration of digital primary sources, 441- 448.

Gagnon, G.W., \& Collay D.M. (2001). Design for learning: Six elements in constructivist classrooms. California: Corwin Press. 
Green, S.B., \& Salkind, N.J. (2017). Using SPSS for windows and macintosh: Analyzing and understanding data. $\left(8^{\text {th }}\right.$ ed.). New York: Pearson.

Griffith, A. (2010). SPSS for dummies ( $2^{\text {nd }}$ ed.). New Jersey: Wiley Publishing Inc.

Hastings, P., Hughes, S., Magliano, J.P., Goldman, S.R. (2012). Assessing the use of multiple sources in student essays. Beh Res, 44, 622-633. doi:10.2758.s13428-012-0214-0

Haycock, C.A. (1991). Resource-based learning: A shift in the roles of teacher, learner. NASSP Bull, $75(535), 15-22$.

Hendrickson, L. (2016). Teaching with artifacts and special collections. Bulletin of the History of Medicine, 90(1), 136-140. Hill, J.R., \& Hannafin, M. J. (2001). Teaching and Learning in digital environments: The resurgence of resource-based learning. Education Technology Research Development, 45(4), 37-64.

Hover, S.V., Hicks, D., \& Dack, H. (2016). From source to evidence? Teachers' use of historical sources in their classrooms. The Social studies, 107(6), 209 -217. doi:10.1080/00377996.2015.1214903

Hynd, C.R. (1999). Teaching students to think critically using multiple texts in history. Journal of Adolescent \& Adult Literacy, 42(6), 428-436.

Johansson, P. (2017). Learning study as a clinical research practice to generate knowledge about the learning of historical primary source analysis. Educational Action Research, 25(1), 167-181. doi:10.1080/09650792.20161270224

Kaplan, R.M., \& Saccuzzo, D.P. (2009). Psychological testing: Principles, applications and issues $\left(7^{\text {th }}\right.$ ed.). Australia: Wadsworth Cengage Learning.

Kaviza, M. (2019). Kesan kaedah Document-based lesson terhadap penaakulan sejarah dalam kalangan murid berbeza tahap pemikiran kritis. Juku: Jurnal Kurikulum \& Pengajaran Asia Pasifik, 7(2), 1-9.

Khoo Kay Kim. (1992). Perkembangan pendidikan sejarah: Sejarah dalam pendidikan persatuan sejarah Malaysia. Kuala Lumpur: Dewan Bahasa dan Pustaka.

Learned, J.E. (2018). Doing history: A study of disciplinary literacy and readers labeled as struggling. Journal of Literacy Research, 50(2), 190-216. doi:10.117711086296x17746446

Lee, J.K. (2002). Digital history in the history/social studies classrooms. The History Teacher, 35(4), $5-8$.

Lezah @ Lejah Kiamsin \& Rosy Talin. (2018). Kaedah pengajaran sejarah yang diminati pelajar dan justifikasinya. Malaysian Journal of Social Sciences and Humanities, 3(2), 137-145.

Levisohn, J.A. (2015). Historical thinking and its alleged unnaturalness. Educational Philosophy and Theory, 1-13. doi:10.1080/00131857.2015.1101364

Malar Muthiah. (2015). Kesan Kaedah Stad Terhadap Kekekalan Pengetahuan Sejarah dan Kemahiran Sosial Murid Tingkatan Dua. Jurnal Kompilasi Kertas Penyelidikan Institut Pendidikan Guru Kampus Sultan Abdul Halim Tahun 2012 hingga 2014. Kedah: Institut Pendidikan Guru

Merkt, M., Werner, M., \& Wagner, W. (2017). Historical thinking skills and mastery of multiple documents tasks. Learning and Individual Differences, 54, 135-146. doi:10.1016/j.indif.2017.01.021

Mink, L. (1987). Historical understanding. Ithaca: Cornell University Press.

Mohamad Rodzi Abdul Razak. (2009). Pembinaan negara bangsa Malaysia: Peranan pendidikan sejarah dan dasar pendidikan kebangsaan. JEBAT: Malaysian Journal of History, Polities \& Strategy, 36, 90-106.

Mohd Samsudin \& Shahizan Shaharuddin. (2012). Pendidikan dan pengajaran mata pelajaran sejarah di sekolah di Malaysia. JEBAT: Malaysian Journal of History, Polities \& Strategy, 39(2), 116141.

Moser, D. (2013). Effects of student engagement with the use of digital primary sources in a high school social studies classroom. Nokes, J.D. (2014). Elementary students' roles and epistemic stances during document based history lessons. Theory \& Research in Social Education, 42, 375413. doi:10.1080/00933104.2014.937546

Nunnally, J.C. (1978). Psychometrie theory (2 ${ }^{\text {nd }}$ ed.). New York: McGraw Hill.

Nur Syazwani Abdul Talib, Kamarulzaman Abdul Ghani, \& Nur Azuki Yusoff. (2016). Tahap pengetahuan dan sikap graduan IPT serta hubungannya dengan minat terhadap sejarah: Usaha awal memupuk semangat cinta negara. Jurnal Pemikir Pendidikan, 7, 57-72. 
Oppong, C.A. (2012). Exploring pupils' historical knowledge within junior high school Studies Course. Procedia Social and Behavioral Sciences, 55, 399-408. doi:10.1016/j.sbspra.2012.09.518

Pallant, J. (2016). SPSS survival manual: A step by step guide to data analysis using IBM SPSS (6 $6^{\text {th }}$ Ed). New York: McGraw Hill Education.

Piaget, J. (1952). The origins of intelligence in children. New York: International Universities Press.

Piaget, J. (1970). Piaget's Theory. In P. Mussen (Eds.), Carmichael's manual of child psychology (pp.703-732). New York: Wiley.

Poulton, H. (1972). The historian's handbook. Norman, Oklahoma: University of Oklahoma Press.

Pusat Perkembangan Kurikulum. (2003). Huraian sukatan pelajaran mata pelajaran sejarah tingkatan empat. Kuala Lumpur: Kementerian Pendidikan Malaysia

Pusat Perkembangan Kurikulum. (2013). Dokumen standard kurikulum dan pentaksiran sejarah tahun empat. Putrajaya: Kementerian Pendidikan Malaysia.

Pusat Perkembangan Kurikulum. (2015). Dokumen standard kurikulum dan pentaksiran mata pelajaran sejarah tingkatan satu. Putrajaya: Kementerian Pendidikan Malaysia.

Putnam, L. (2016). The transnational and the text-searchable: Digitized sources and the shadows the cast. The American Historical Review, 121(2), 377-402. doi: 10.1093/ahr/121.2.377

Reisman, A. (2012). The "document-based lesson": Bringing disciplinary inquiry into high school history classrooms with adolescent struggling readers. Journal of Curriculum Studies, 44(2), 233264. doi: $10.1080 / 00220272.2011 .591436$

Reisman, A. (2017). Integrating content and literacy in social studies: Assessing instructional materials and student work from a common core-aligned intervention. Theory \& Research in Social Education, 1-38. Doi: 10.1080/00933104.2017.1292162

Richter, T., \& Maier, J. (2017). Comprehension of multiple documents with conflicting information: A two-step model of validation. Educational Psychologist, 5(3), 148-166. doi:10.1080/00461520.2017.1322968

Roberts, S.L. (2011). Using counterfactual history to enhance student's historical understanding. The Social Studies, 102(3), 117-123. doi:10.1080/00377996.2010.525547

Rouet, J.F., Britt, M.A., \& Mason, R.A., \& Perfetti, C.A. (1996). Using multiple sources of evidence to reason about history. Journal of Educational Psychology, 88(3), 478-493.

Samuelsson, J., \& Wendell, J. (2016). Historical thinking about sources in the context of a standardsbased curriculum: A Swedish case. The Curriculum Journal, 27(4), 479-499. doi:10.1080/09585176.2016.1195275

Sell, C.R., \& Griffin, K. (2017). Powerful social studies teaching with poetry and primary sources. The Social Studies, 108(1), 1-9. doi:10.1080/00377996.2016.1237464

Sharifah Aini Jaafar \& Arba'iyah Mohd Noor. (2016). Pelaksanaan pengajaran dan pembelajaran sejarah di sekolah-sekolah di Malaysia, 1957-1989. Sejarah, 25(2), 40-57.

Sheehan, M. (2013). Better to do than receive: Learning to think historically through internally assessed course work. Teaching \& Learning Research Initiative, 1-13.

Spiro, R., Coulson, R.L., Feltovisch, P.J., \& Anderson, D.C. (1988, Ogos). Cognitive flexibility theory: Advanced knowledge acquisition in ill-structured domains. Kertas kerja yang dibentangkan di $10^{\text {th }}$ Annual Conference of the Cognitive Science, \& Society, Montreal, New Jersey.

Spiro, R.J., \& Jehng, J.C. (1990). Cognitive flexibility and hypertext: Theory and technology for nonlinear and multidimensional traversal of complex subject matter. In D. Nix \& R. J. Spiro (Eds.), Cognition, education and multimedia: exploring ideas in high technology (pp. 163-205). Hillsdale: Lawrence Erlbaum Associates.

Stephens, R.P., Lehr, J.L, Thorp, D.B., Ewing, E.T \& Hicks, D. (2005). Using technology to teach historical understanding: The digital history reader brings the possibilities of new technology to the history classroom. Social education, 151(4), 1-6.

Suh, Y. (2013). Past looking: Using arts as historical evidence in history teaching. The Social Studies Research and Practice, 8(1), 135-159.

Tan, H.D. (2004). What is history teaching and learning? Teaching and Learning 25(2), 197-206.

Thangamalar Paramasivam \& Nagendralingam Ratnavadivel. (2018). Issues and challenges in managing curriculum change in primary schools: A case study of managing year four history curriculum in the district of Kuala Selangor, Malaysia. Journal of Research, Policy \& Practice of Teachers \& Teacher Education, 8(1), 18-31. 
Thornton, S.J. (2005). Teaching social studies that matters. New York: Teachers College Press.

Tomsic, M., \& Deery, C.M. (2019). Creating 'them' and 'us': The educational framing of picture books to teach about forced displacement and todays 'refugee crisis'. History of Education Review, 1-16. doi: 10.1108/HER-11-2018-0027

Tyman, T., McCleery, J., \& Tindal, G. (2006). Using concepts to frame history content. The Journal of Experimental Education, 74(4), 331-349.

VanSledright, B.A., \& Kelly, C. (1998). Reading American history: The influence of multiple sources on six fifth graders. The Elementary School Journal, 98(3), 239-265.

Wagner, D-A. (2018). Teachers' use of film in the history classroom: A Survey of 19 high school teachers in Norway. Journal of Humanities and Social science Education, 1, 22-44.

Woyshner, C. (2010). Inquiry teaching with primary source documents: An iterative approach. Social Studies Research and Practice, 5(3), 36-45.

Zaccaria, M.A. (1978). The development of historical thinking: Implications for the teaching of history. The History Teacher, 11(3), 323-340. 